\title{
Ice triaxial deformation and fracture
}

\author{
M. A. RIST* \\ NRC Institute for Marine Dynamics, St. Fohn's, Newfoundland A1A 3T5, Canada \\ S. A. F. MURRELL \\ Department of Geological Sciences, University College London, London WC1E 6BT, England
}

\begin{abstract}
An experimental investigation into the mechanical behaviour of polycrystalline ice in triaxial compression has been conducted using conditions generally favourable to brittle fracture and microcracking. Under triaxial stresses at high strain rate, ice failure occurs by abrupt shear fracturing, generally inclined at about $45^{\circ}$ to the maximum principal stress. At $-20^{\circ} \mathrm{C}$, such failure is suppressed by the imposition of a small confining pressure, allowing a transition to ductile-type flow accompanied by distributed microcracking, but at $-40^{\circ} \mathrm{C}$ shear fracture persists under confinement of up to at least $50 \mathrm{MPa}$. For low confining pressures $(<10 \mathrm{MPa})$, brittle strength is strongly pressure-dependent; above this it is pressure-independent. Evidence is presented that suggests this may reflect a change from a fracture process influenced by friction to fracture initiated by localized yielding. Ductile yield strength is found to be little influenced by confining pressure despite the inhibition of cracking that leads to greatly contrasting observed crack densities. Flow conforms to the well-known power law for ice with $Q=69 \mathrm{~J} \mathrm{~mol}^{-1}$ and $n=4.2$ over the temperature range $-20^{\circ}$ to $-45^{\circ} \mathrm{C}$. Under these conditions, microcracking in ice appears to remain remarkably stable and non-interacting.
\end{abstract}

\section{INTRODUCTION}

The fundamental mechanics of ice deformation is important in understanding and interpreting a wide range of complex processes, both in the Earth's dynamics and for practical engineering or environmental reasons. Although ice is a remarkably brittle solid compared to other materials at high homologous temperatures, much work has concentrated on the creep and plasticity of ice because these processes are known to dominate under the small deviatoric stresses found in glaciers and ice sheets. However, ice fracture is significant in many different aspects of ice behaviour. The interactions between ice floes and offshore structures or marine vessels take place at deformation rates high enough to give rise to a complex combination of mechanical processes including creep, shear and tensile fracture, frictional heating and icerubble pile-up (see, for example, Hallam, 1986; Sanderson, 1988). The calving of icebergs and ice islands from ice shelves takes place by mechanisms combining both fracture and plastic flow (Hughes, 1983) and brittle processes generally may have a strong influence on Antarctic ice-shelf stability (Doake and Vaughan, 1991). Brittle crevassing in glaciers, although irrelevant to

* Present address: Department of Geological Sciences, University College London, London WC1E 6BT, England. overall deformation, has also been used recently to infer in-situ stresses in large ice masses (Vaughan, 1993).

Despite the importance of brittle failure, no satisfactory mechanistic fracture criterion exists for ice that can be applied either to ice-structure interactions or to glacier and ice-shelf deformation. Brittle cleavage and fracture, unlike plastic flow, are strongly influenced by hydrostatic confinement and part of the problem has been the shortage of systematic experimental investigation into brittle-ice properties under complex states of stress. Polyaxial tests, in which all three principal stresses are varied independently, have been attempted (Hausler, 1981; Schulson and others, 1991) but triaxial testing, in which a uniaxial stress and a hydrostatic pressure are superimposed, has proved a more practical means of promoting a uniform stress field in small specimens and is widely employed in rock-mechanics testing. For this study, a conventional triaxial cell was used to investigate ice-mechanical behaviour at temperatures between $-20^{\circ}$ and $-45^{\circ} \mathrm{C}$, using pressures generally below $30 \mathrm{MPa}$ and strain rates high enough to promote crack growth and macroscopic fracture. It was not intended that these experimental conditions should necessarily simulate any specific natural loading condition, rather that they should promote similar brittle-deformation processes that could be studied systematically in the laboratory. This work is part of a wider study overviewed by Murrell and others (1991) and ice triaxial fracture has also been specifically investigated by Durham and others (1983). Other triaxial studies have concentrated mainly on ductile-type flow in 
confinement (Jones, 1982; Cox and Richter-Menge 1986; Nadreau and Michel, 1986), although more recent emphasis has been placed on crack nucleation and damage (Kalifa and others, 1989, 1992; Stone and others, 1989).

When considering the three-dimensional state of stress in a material, it is convenient to distinguish three mutually perpendicular directions in which shear stresses vanish, and which define the directions of the purely normal principal stresses $\sigma_{1}, \sigma_{2}$ and $\sigma_{3}$. The convention adopted here is that which is most used in the geological sciences whereby $\sigma_{1} \geq \sigma_{2} \geq \sigma_{3}$ and compressive stresses are assumed positive. During our triaxial tests a hydrostatic pressure and a uniaxial stress are superimposed upon right-circular cylinders as illustrated in Figure 1. In

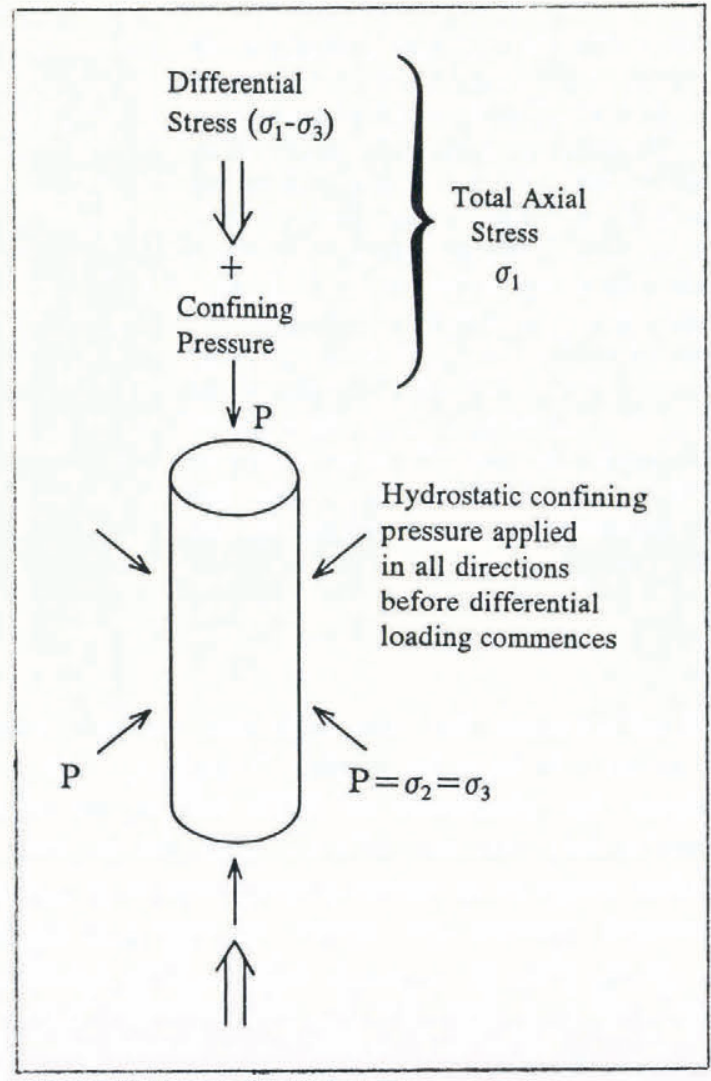

Fig. 1. Triaxial loading arrangement.

effect, a compressive axial stress $\sigma_{1}$ is applied to specimens under confining pressure $P=\sigma_{2}=\sigma_{3}$ such that $\sigma_{1}>$ $\sigma_{2}=\sigma_{3}$ and the imposed differential stress in the axial direction is $\left(\sigma_{1}-\sigma_{3}\right)$. A plane inclined at an angle $\theta$ to $\sigma_{1}$ experiences a normal stress, $\sigma_{\mathrm{n}}$, and a shear stress, $\tau$, given by

$$
\begin{aligned}
\sigma_{\mathrm{n}} & =\frac{1}{2}\left(\sigma_{1}+\sigma_{3}\right)-\frac{1}{2}\left(\sigma_{1}-\sigma_{3}\right) \cos 2 \Theta \\
\tau & =-\frac{1}{2}\left(\sigma_{1}-\sigma_{3}\right) \sin 2 \Theta
\end{aligned}
$$

The mean normal stress, $\sigma_{\mathrm{m}}$, in all directions is $\frac{1}{3}\left(\sigma_{1}+\sigma_{2}+\sigma_{3}\right)$ and may be considered to act as a hydrostatic stress that changes as the specimen undergoes differential loading.

\section{TRIAXIAL TESTING SYSTEM}

The purpose-built triaxial deformation cell used in this study is based on triaxial rock-testing apparatus of conventional design, incorporating a pressure-balanced loading ram. The system, described in detail by Sammonds and others (1991), operates under closedloop servo-control and has the capability of reaching pressures up to $300 \mathrm{MPa}$ and temperatures down to $-90^{\circ} \mathrm{C}$.

Basically, a thick-walled pressure vessel, along with a system of plugs and retaining nuts, is used to contain nitrogen gas at high pressure around a jacketed cylindrical sample whilst a ram, loaded by an external actuator, moves along sliding seals to deform the specimen. The jackets, made of soft indium metal, are necessary to protect the ice from pressurized gas which would otherwise cause damage by exploiting surface flaws. The vessel and loading components are contained within a $-20^{\circ} \mathrm{C}$ cold room and further cooling is provided by circulating refrigerant around the vessel from a lowtemperature bath. Confining gas is supplied by an external gas booster-intensifier system.

Differential load is applied via steel end caps with strict alignment being maintained by small clearances between loading ram and seal housings. Specimen dimensions ( $40 \mathrm{~mm}$ diameter by $100 \mathrm{~mm}$ long) provide a length:diameter ratio of 2.5:1 in accordance with standard practice in rock-mechanics testing (Jaeger and Cook, 1979), promoting a uniform stress field in the central part of the specimen without tending to induce buckling. In the brittle regime, where deformation is predominantly elastic, a more uniform stress field is maintained in the presence of a confining pressure than can be achieved during simple uniaxial compression (e.g. see Brady, 1971), although significant stress homogeneity may still occur during ductile deformation.

Both load and displacement are measured externally. The load cell, between the actuator and pressurebalanced ram, records the differential load on the specimen (over and above the confining pressure) plus a small constant load due to sliding against seal friction. The latter is easily measured and eliminated for each test by allowing sliding against seals only, before loading of the specimen commences. Displacement is recorded using a transducer attached to the top of the loading ram, which means that deformation of both specimen and ram is measured. However, specimen-based deformation control and a constant specimen strain rate are still maintained by subtracting the contribution due to elastic ram deformation from the total strain signal within the servo-control loop. Such precautions are essential because of the strain-rate sensitivity of ice-deformation behaviour, and the overall effectiveness of this technique has been fully demonstrated (Rist and others, 1991). Fixed strain rate is well maintained throughout the progress of a test, although there is some effect during the initiation of loading due to the nature of the interface between ice and end caps.

\section{SPECIMEN PREPARATION}

A systematic investigation of ice-mechanical behaviour using the current triaxial-testing system requires cylindrical specimens of fine-grained, isotropic ice which are of a consistent, reproducible quality. To this end, high-density 
ice specimens consisting of randomly oriented grains of uniform size are routinely manufactured.

The technique has been developed following the method of Jacka and Lile (1984) in which crushed pure-ice seeds are mixed with cold de-aerated water to form an ice-water slurry that is compressed into a cylindrical mould and quickly frozen. Porosity is kept to a minimum as most of the pore water in which bubbles may form is expelled during compaction. However, the specimens are not entirely bubble-free, and have an overall hazy appearance with bubble sizes of generally less than $0.1 \mathrm{~mm}$ diameter. Nevertheless, the amount of included air is small, as reflected in the mean bulk density of $914 \pm 1 \mathrm{~kg} \mathrm{~m}^{-3}$ and specimens are of a highly reproducible quality. Specimen thin sections viewed through crossed polaroids display good general homogeneity right across the diameter and no change in fabric near the sample walls. Mean grain diameter was $1.7 \mathrm{~mm}$ as determined by counting the number of grains per unit area in thin section and assuming spherical geometry. Meltwater conductivity of the specimens was lower than
$10 \times 10^{-3} \mathrm{~S} \mathrm{~m}^{-1}$, not significantly different from the distilled water from which they were made.

\section{TEST PROCEDURE}

Immediately prior to testing, specimens were removed from their moulds and machined to the correct length, with their ends parallel to within $\pm 0.03 \mathrm{~mm}$. The ice was jacketed using indium and assembled between the upper and lower loading rams which were then aligned and lowered into the pressure vessel. The entire apparatus was allowed to equilibrate so that temperature did not fluctuate by more than $\pm 0.2^{\circ} \mathrm{C}$ once testing had commenced. For confined tests, nitrogen gas was pumped into the cell and maintained at a set pressure to within $\pm 3 \%$. Pumping could take several minutes at the higher pressures used here but a series of vents ensured that a true hydrostatic confinement was always maintained around the specimen during this period. For the test proper, the actuator advanced at a constant specimendisplacement rate and deformation was allowed to

Table 1a. Summary of test results at $-20^{\circ} \mathrm{C}$

\begin{tabular}{|c|c|c|c|c|c|c|}
\hline $\begin{array}{c}\text { Test } \\
\text { specimen } \\
\text { No. }\end{array}$ & $\begin{array}{c}\text { Temp } \\
T\end{array}$ & $\begin{array}{c}\text { Strain } \\
\text { rate } \\
\dot{\epsilon} \\
\mathrm{s}^{-1}\end{array}$ & $\begin{array}{c}\text { Confining } \\
\text { pressure } \\
P=\sigma_{3} \\
\mathrm{MPa}\end{array}$ & $\begin{array}{c}\text { Failure } \\
\text { stress } \\
\sigma_{1}-\sigma_{3} \\
\mathrm{MPa}\end{array}$ & $\begin{array}{c}\text { Failure } \\
\text { strain } \\
\epsilon_{\mathrm{f}} \\
\%\end{array}$ & Mode of deformation \\
\hline 43 & -20.0 & $10^{-2}$ & 0.1 & 18.0 & 0.32 & Brittle; axial splitting \\
\hline 51 & -20.4 & $10^{-2}$ & 0.5 & 21.7 & 0.45 & Brittle; shear fracture \\
\hline 37 & -20.0 & $10^{-2}$ & 1.0 & 25.7 & 0.55 & Brittle; shear fracture \\
\hline 39 & -20.1 & $10^{-2}$ & 2.4 & 28.4 & 0.76 & Ductile; dense cracking \\
\hline 19 & -20.0 & $10^{-2}$ & 4.8 & 32.1 & 0.68 & Ductile; (jacket leak) \\
\hline 31 & -20.3 & $10^{-2}$ & 10.3 & 33.4 & 0.71 & Ductile; dense cracking \\
\hline 34 & -19.8 & $10^{-2}$ & 19.8 & 34.6 & 0.78 & Ductile; dense cracking \\
\hline 66 & -19.9 & $10^{-2}$ & 28.5 & 32.4 & 0.83 & Ductile; intermediate cracking \\
\hline 77 & -19.9 & $10^{-2}$ & 30.0 & 32.8 & 0.81 & Ductile; intermediate cracking \\
\hline 41 & -20.0 & $10^{-3}$ & 0.1 & 14.2 & 0.40 & Ductile; dense cracking \\
\hline 38 & -19.9 & $10^{-3}$ & 0.8 & 15.2 & 0.49 & Ductile; dense cracking \\
\hline 24 & -20.1 & $10^{-3}$ & 4.6 & 18.9 & 0.55 & Ductile; dense cracking \\
\hline 18 & -19.7 & $10^{-3}$ & 5.0 & 19.3 & 0.52 & Ductile; dense cracking \\
\hline 78 & -19.8 & $10^{-3}$ & 10.3 & 18.5 & 1.07 & Ductile; dense cracking \\
\hline 23 & -20.0 & $10^{-3}$ & 11.1 & 18.4 & 0.80 & Ductile; (jacket leak) \\
\hline 416 & -20.5 & $10^{-3}$ & 19.9 & 20.4 & 1.20 & Ductile; intermediate cracking \\
\hline 35 & -20.0 & $10^{-3}$ & 29.7 & 20.2 & 1.38 & Ductile; intermediate cracking \\
\hline 42 & -19.5 & $10^{-4}$ & 0.1 & 6.5 & 0.47 & Ductile; dense cracking \\
\hline 36 & -20.0 & $10^{-4}$ & 4.7 & 10.5 & 0.86 & Ductile; dense cracking \\
\hline 26 & -19.7 & $10^{-4}$ & 9.8 & 11.9 & 1.10 & Ductile; intermediate cracking \\
\hline 30 & -20.1 & $10^{-4}$ & 19.9 & 12.2 & 1.14 & Ductile; intermediate cracking \\
\hline 48 & -20.1 & $10^{-4}$ & 28.8 & 12.0 & 1.11 & Ductile; sparse cracking \\
\hline 111 & -20.8 & $10^{-5}$ & 4.8 & 8.0 & 1.23 & Ductile; intermediate cracking \\
\hline 114 & -20.2 & $10^{-5}$ & 9.8 & 7.8 & 1.13 & Ductile; intermediate cracking \\
\hline 83 & -19.6 & $10^{-5}$ & 19.8 & 9.5 & 1.38 & Ductile; no cracks \\
\hline 414 & -19.7 & $10^{-5}$ & 30.0 & 7.6 & 1.23 & Ductile; no cracks \\
\hline
\end{tabular}


Table 1b. Summary of test results at $-40^{\circ} \mathrm{C}$

\begin{tabular}{rcccccl}
\hline $\begin{array}{c}\text { Test } \\
\text { specimen }\end{array}$ & $\begin{array}{c}\text { Temp. } \\
\text { No. }\end{array}$ & $\begin{array}{c}\text { Strain } \\
\text { rate }\end{array}$ & $\begin{array}{c}\text { Confining } \\
\text { pressure } \\
P=\sigma_{3}\end{array}$ & $\begin{array}{c}\text { Failure } \\
\text { stress } \\
\sigma_{1}-\sigma_{3} \\
\mathrm{MPa}\end{array}$ & $\begin{array}{c}\text { Failure } \\
\text { strain } \\
\epsilon_{\mathrm{f}}\end{array}$ & $\begin{array}{l}\text { Mode of deformation } \\
\%\end{array}$ \\
\hline 97 & ${ }^{\circ} \mathrm{C}$ & $\mathrm{s}^{-1}$ & $\mathrm{MPa}$ & $\mathrm{MPa}$ & \\
\hline 106 & -39.4 & $10^{-2}$ & 0.3 & 27.5 & 0.39 & Brittle; axial splitting \\
102 & -39.0 & $10^{-2}$ & 0.8 & 32.6 & 0.49 & Brittle; shear fracture \\
501 & -39.3 & $10^{-2}$ & 2.0 & 36.8 & 0.55 & Brittle; shear fracture \\
105 & -39.9 & $10^{-2}$ & 2.9 & 40.8 & 0.49 & Brittle; shear fracture \\
56 & -38.4 & $10^{-2}$ & 3.2 & 35.9 & 0.50 & Brittle; shear fracture \\
88 & -40.4 & $10^{-2}$ & 4.8 & 45.7 & 0.63 & Brittle; shear fracture \\
85 & -40.6 & $10^{-2}$ & 7.1 & 49.6 & 0.68 & Brittle; shear fracture \\
96 & -39.4 & $10^{-2}$ & 9.6 & 52.6 & 0.79 & Brittle; shear fracture \\
101 & -38.4 & $10^{-2}$ & 24.9 & 54.7 & 0.98 & Brittle; shear fracture \\
419 & -39.4 & $10^{-2}$ & 29.9 & 59.0 & 0.92 & Brittle; shear fracture \\
& -39.9 & $10^{-2}$ & 46.0 & 59.0 & 0.99 & Brittle; shear fracture \\
44 & & & & & & \\
58 & -39.5 & $10^{-3}$ & 0.1 & 27.4 & 0.49 & Brittle; axial splitting \\
52 & -40.0 & $10^{-3}$ & 0.3 & 27.9 & 0.49 & Brittle; axial splitting \\
49 & -40.8 & $10^{-3}$ & 4.3 & 35.8 & 0.88 & Ductile; dense cracking \\
57 & -39.6 & $10^{-3}$ & 9.8 & 35.2 & 0.74 & Ductile; dense cracking \\
& -39.9 & $10^{-3}$ & 19.7 & 37.1 & 0.79 & Ductile; dense cracking \\
45 & & & & & & \\
107 & -39.6 & $10^{-4}$ & 0.1 & 16.6 & 0.44 & Ductile; dense cracking \\
108 & -40.0 & $10^{-4}$ & 4.8 & 21.0 & 0.61 & Ductile; dense cracking \\
& -42.2 & $10^{-4}$ & 29.6 & 24.1 & 1.49 & Ductile; jacket leak) \\
\hline
\end{tabular}

Table 1c. Summary of test results at various temperatures with a confining pressure of $5 \mathrm{MPa}$

\begin{tabular}{|c|c|c|c|c|c|c|}
\hline \multirow[t]{2}{*}{$\begin{array}{c}\text { Test } \\
\text { specimen } \\
\text { No. }\end{array}$} & $\begin{array}{c}\text { Temp } \\
T\end{array}$ & $\begin{array}{c}\text { Strain } \\
\text { rate } \\
\dot{\epsilon}\end{array}$ & $\begin{array}{c}\text { Confining } \\
\text { pressure } \\
P=\sigma_{3}\end{array}$ & $\begin{array}{c}\text { Failure } \\
\text { stress } \\
\sigma_{1}-\sigma_{3}\end{array}$ & $\begin{array}{c}\text { Failure } \\
\text { strain } \\
\epsilon_{\mathrm{f}}\end{array}$ & \multirow[t]{2}{*}{ Mode of deformation } \\
\hline & ${ }^{\circ} \mathrm{C}$ & $\mathrm{s}^{-1}$ & $\mathrm{MPa}$ & $\mathrm{MPa}$ & $\%$ & \\
\hline 89 & -9.9 & $10^{-2}$ & 4.9 & 22.4 & 0.57 & Ductile; dense cracking \\
\hline 90 & -24.2 & $10^{-2}$ & 4.8 & 36.0 & 0.84 & Ductile; dense cracking \\
\hline 53 & 5.2 & $10^{-3}$ & 4.9 & 9.7 & 1.00 & Ductile; intermediate cracking \\
\hline 75 & -10.0 & $10^{-3}$ & 4.7 & 12.0 & 0.86 & Ductile; dense cracking \\
\hline 70 & -14.8 & $10^{-3}$ & 4.8 & 14.2 & 0.59 & Ductile; dense cracking \\
\hline 69 & -29.4 & $10^{-3}$ & 4.9 & 25.7 & 0.56 & Ductile; dense cracking \\
\hline 72 & -36.1 & $10^{-3}$ & 4.9 & 28.3 & 0.78 & Ductile; dense cracking \\
\hline 98 & -37.9 & $10^{-3}$ & 4.8 & 31.6 & 0.64 & Ductile; (jacket leak) \\
\hline 73 & -44.7 & $10^{-3}$ & 4.8 & 41.2 & 0.76 & Ductile; dense cracking \\
\hline 92 & -4.9 & $10^{-4}$ & 4.9 & 6.1 & 1.00 & Ductile; intermediate cracking \\
\hline 91 & -11.0 & $10^{-4}$ & 4.9 & 8.2 & 1.07 & Ductile; intermediate cracking \\
\hline 94 & -28.9 & $10^{-4}$ & 4.8 & 13.1 & 0.76 & Ductile; dense cracking \\
\hline 93 & -5.4 & $10^{-5}$ & 4.8 & 3.5 & 0.95 & Ductile; no cracks (jacket leak) \\
\hline 104 & -9.6 & $10^{-5}$ & 4.8 & 4.6 & 1.34 & Ductile; intermediate cracking \\
\hline 99 & -27.9 & $10^{-5}$ & 4.7 & 8.3 & 1.34 & Ductile; dense cracking \\
\hline
\end{tabular}


proceed to a maximum of $5 \%$ strain where possible. On completion of a test, the specimen was immediately unloaded, the vessel disassembled and a visual inspection of the deformed ice was conducted.

\section{TEST RESULTS}

The results from 61 constant strain-rate tests are summarized in Table 1. Two series of tests were conducted to investigate the influence of confining pressure and strain rate at fixed nominal temperatures of $-20^{\circ}$ and $-40^{\circ} \mathrm{C}$, and a further set of tests was conducted at various temperatures and strain rates with a fixed nominal confining pressure of $5 \mathrm{MPa}$. Some test results are included for which a jacket leak occurred but which did not appear to affect the specimen strength, presumably because this arose during the latter part of the test.

The stated failure strain $\left(\epsilon_{\mathrm{f}}\right)$ in Table 1 is measured externally and includes interface effects which are more pronounced at low stresses. These values are, therefore, an overestimate of the true specimen strain at failure.

Other specific aspects of the overall results are explained and examined in detail below.

\section{Failure mode}

\section{Brittle fracture}

Brittle failure was generally characterized by a predominantly linear increase of stress with strain (Fig. 2), climaxed by an audible report from the specimen at peak stress, and followed by a large stress drop which was marked by a momentary loss of control of the test-system actuator. Inspection of the deformed specimens revealed two modes of brittle failure depending on whether the state of stress during the test was uniaxial or triaxial:

(a) Uniaxial fracture. With no confining pressure, both axial fractures and an accompanying shear zone were

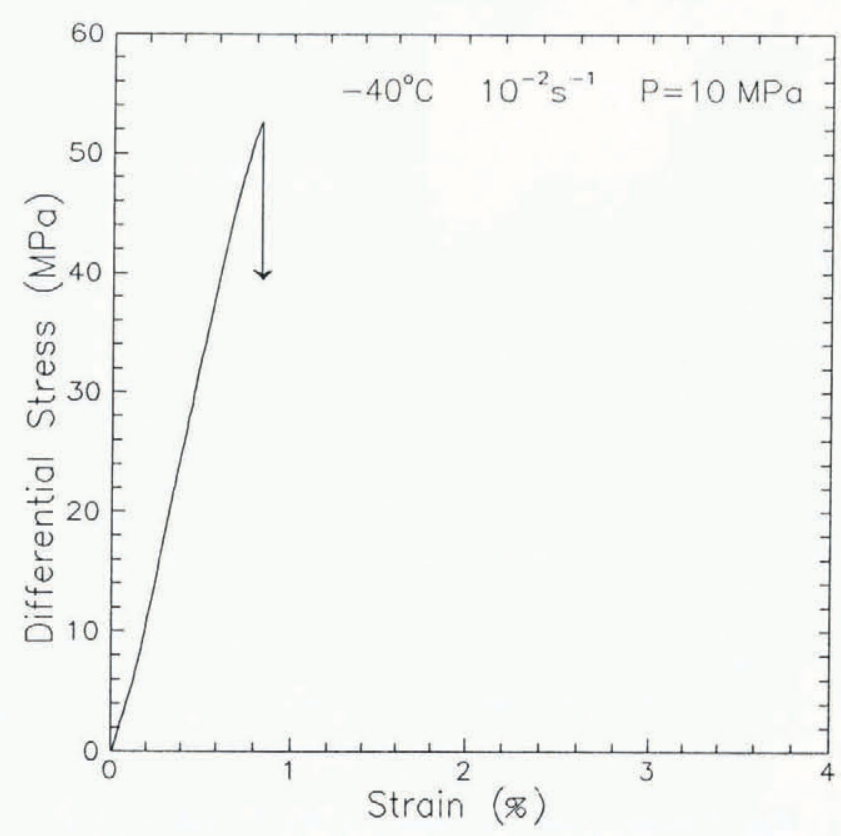

Fig. 2. Stress-strain behaviour for brittle failure at $-40^{\circ} \mathrm{C}$ with $10 \mathrm{MPa}$ confining pressure. observed to run almost from end to end in the specimen (Fig. 3a). The shear fault generally appeared as a wide $(1-3 \mathrm{~cm})$ band of smaller fractures and was inclined at an angle of about $30^{\circ}$ to the direction of $\sigma_{1}$. A brittle solid in such uniaxial compression is frequently observed to fail by axial splitting alone, due simply to the extension of tensile cracking in a direction parallel to the least-compressive stress (see Paterson, 1978; Jaeger and Cook, 1979). However, at high strain rates, frictional constraints between ice and end caps appear to have been large enough effectively to confine the sample at its ends and thus prevent the axial fractures from propagating the entire specimen length. As a result, ultimate failure has occurred by other favourably oriented cracks linking to form a shear zone. Failure of this type is therefore classified as "axial splitting" in Table 1 but it is really a mixed-mode fracture caused by the non-uniformity of stress within the specimen and will not be discussed further.

(b) Triaxial fracture. Under triaxial stresses, brittle failure was characterized by the formation of a single predominant shear fracture, often independent of the specimen ends and generally inclined at an angle of $45 \pm 5^{\circ}$ to the maximum principal stress (Fig. $3 \mathrm{~b}$ ), regardless of the magnitude of the stresses. Interaction of the fault with the specimen ends tended to distort the plane of fracture but did not produce an anomalously low strength. The width of the fault zone was quite narrow, often less than one grain diameter when observed in thin section (but depending on the amount of post-failure sliding), and specimens generally contained few cracks elsewhere. In some cases, however, large secondary cracks were seen to extend perpendicular to the principal fracture surface (Fig. 3c) and are assumed to have occurred as the two halves of the specimen slid over each other after failure.

For most tests that failed in a brittle manner, rupture of the indium jacket occurred and hence postfailure sliding generally took place under uniaxial stress. The sole exception to this was test 419 in which the jacket remained intact and triaxial stresses were maintained so that the specimen displayed stick-slip behaviour after the initial fracture, as shown in Figure 4. This test, conducted at $-40^{\circ} \mathrm{C}$ with the highest confining pressure used $(46 \mathrm{MPa})$, also displayed marked non-linearity in its stress-strain curve prior to fracture.

Brittle $45^{\circ}$ shear fracture of the type described above has also been observed in pure granular ice by Durham and others (1983) at temperatures below $-78^{\circ} \mathrm{C}$ and in sea ice by Sammonds and others (1989).

\section{Ductile failure}

Specimens that failed in a macroscopically ductile manner showed no signs of discontinuity in their stressstrain curves. Typical examples shown in Figure 5 display some apparent linear-elastic deformation (after initial settling down), then a period of non-elastic strain hardening up to a peak stress (failure), followed by strain softening that tended towards a steady-state value at higher strains. The extent of all these features depended 


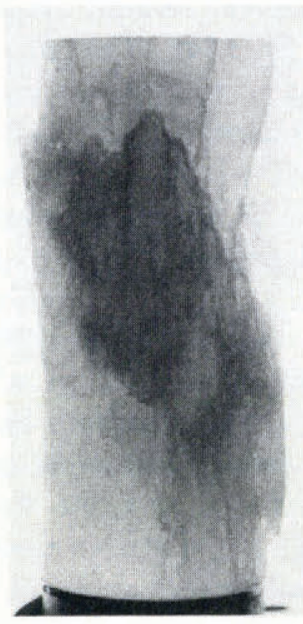

a

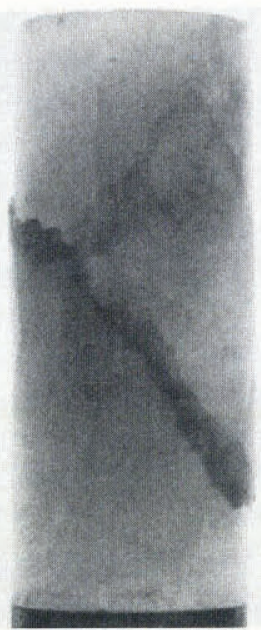

b

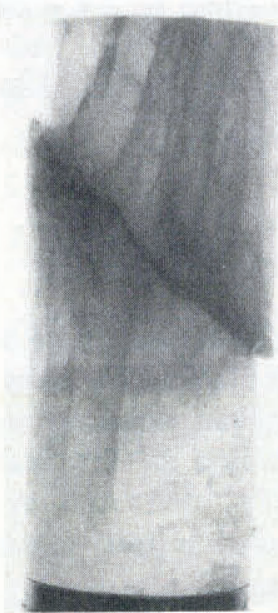

c

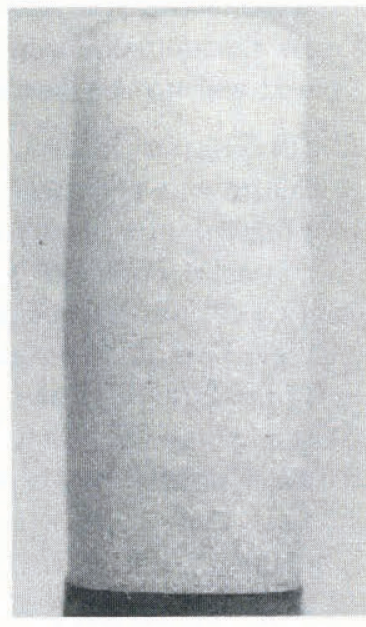

d

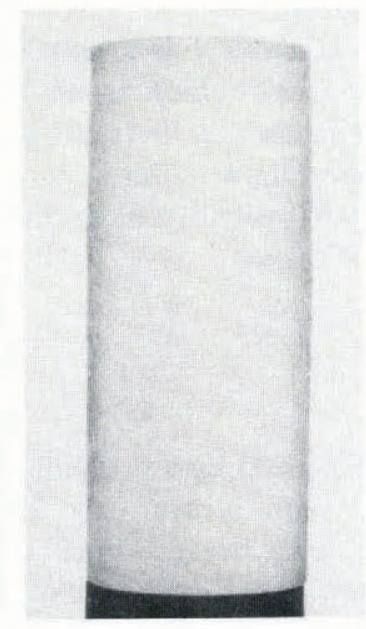

Fig. 3. Deformed brittle specimens displaying (a) axial splitting with accompanying shear zone, (b) and (c) shear fracture; and deformed ductile specimens with (d) dense cracking and (e) minimal cracking activity.

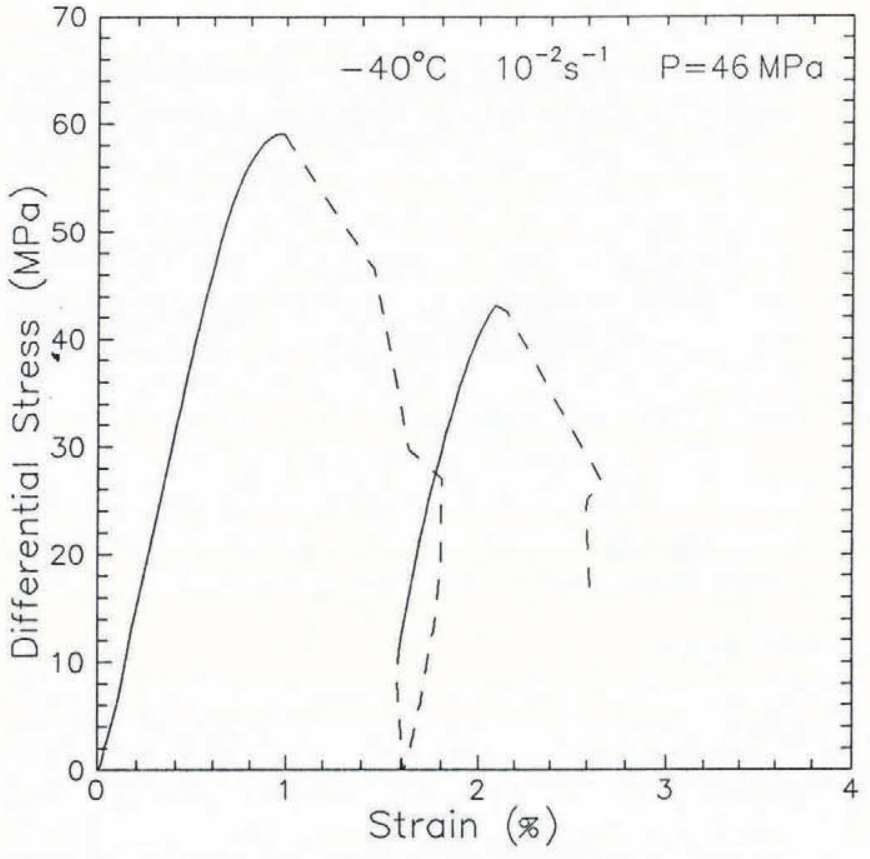

Fig. 4. Stress-strain behaviour for brittle failure at $-40^{\circ} \mathrm{C}$ with $10 \mathrm{MPa}$ confining pressure. Intact specimen jacket allowed post-failure stick-slip sliding under triaxial stress.

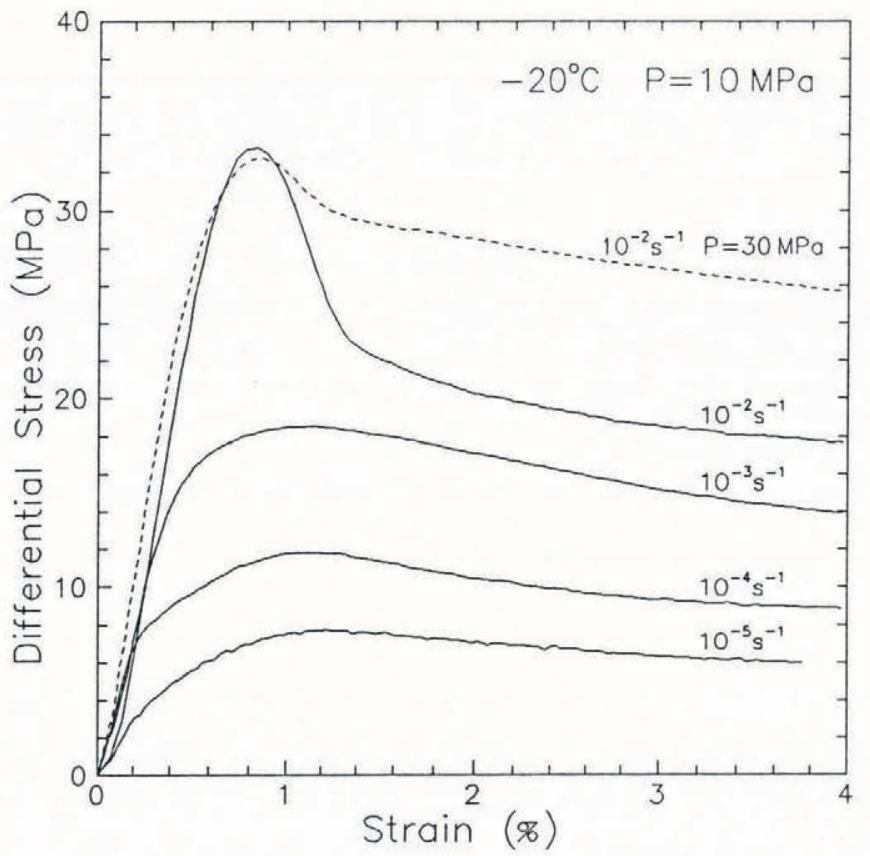

Fig. 5. Stress-strain behaviour for ductile failure under various loading conditions at $-20^{\circ} \mathrm{C}$. 
strongly on temperature, strain rate and confining pressure. Such deformed specimens would generally contain a number of small (1-2 mm) cracks that had not interacted to the extent where a macroscopic fault was formed but had led to the barrelling of the specimen and a generally opaque appearance (Fig. 3d). Where cracking was not too dense, these cracks were observed to be aligned predominantly with their long axes parallel to the direction of the maximum principal compressive stress under both uniaxial and triaxial stress conditions. Crack density varied according to the experimental conditions and could be relatively sparse, in which case barrelling was less pronounced or non-existent (Fig. 3e).

An attempt was made to classify the extent of cracking activity, simply based on a visual inspection of the bulk specimen after testing. Consequently, specific nomenclature has been used to describe the observed crack densities of the deformed ductile specimens in Table 1 and elsewhere, as defined below:

Dense cracking:

A myriad of small cracks throughout the specimen, too dense to be individually identified; many linking to form larger cracks.

\section{Intermediate Specimen opaque with small, cracking: grain-sized cracks, distinguish- able as individual entities.}

Sparse cracking:

No cracks or a few isolated grain-sized cracks.

Although the distinction between dense and intermediate cracking is somewhat subjective, the difference between densely and sparsely cracked specimens is quite distinct (cf. Fig. 3d and e), and the classification assists description and discussion in the following text.

\section{General deformation and strength behaviour}

Deformation at fixed temperature was greatly influenced by both confining pressure and strain rate. Variation of strain rate had a marked influence on stress-strain history and strength as illustrated in Figure 5 for tests at $-20^{\circ} \mathrm{C}$ and $P=10 \mathrm{MPa}$. As strain rate is lowered from $10^{-2} \mathrm{~s}^{-1}$, the peak stress decreases and is reached at an increasingly larger strain, the relative stress drop after failure also decreases and a knee becomes apparent in the curves, although this may again become less distinct as the strain rate is decreased further to $10^{-5} \mathrm{~s}^{-1}$. This double-yield feature is noted elsewhere for pure ice (e.g. Mellor and Cole, 1982) and sea ice (Cox and Richter-Menge, 1986), and initial yield has been associated with the onset of internal cracking. Examination of acoustic emissions reflecting microcrack development does confirm that the start of significant activity often coincides with this point (see Rist and Murrell, 1990; Murrell and others 1991), although events do commence at somewhat lower stresses.

Generally, the effect of increasing confining pressure at fixed temperature and strain rate was to inhibit brittle failure and crack growth. For ductile specimens, the stress drop after failure generally becomes a smaller proportion of the peak stress and crack density decreases $\left(\right.$ see $10^{-2} \mathrm{~s}^{-1}$ tests in Figure 5), although this effect is less pronounced at

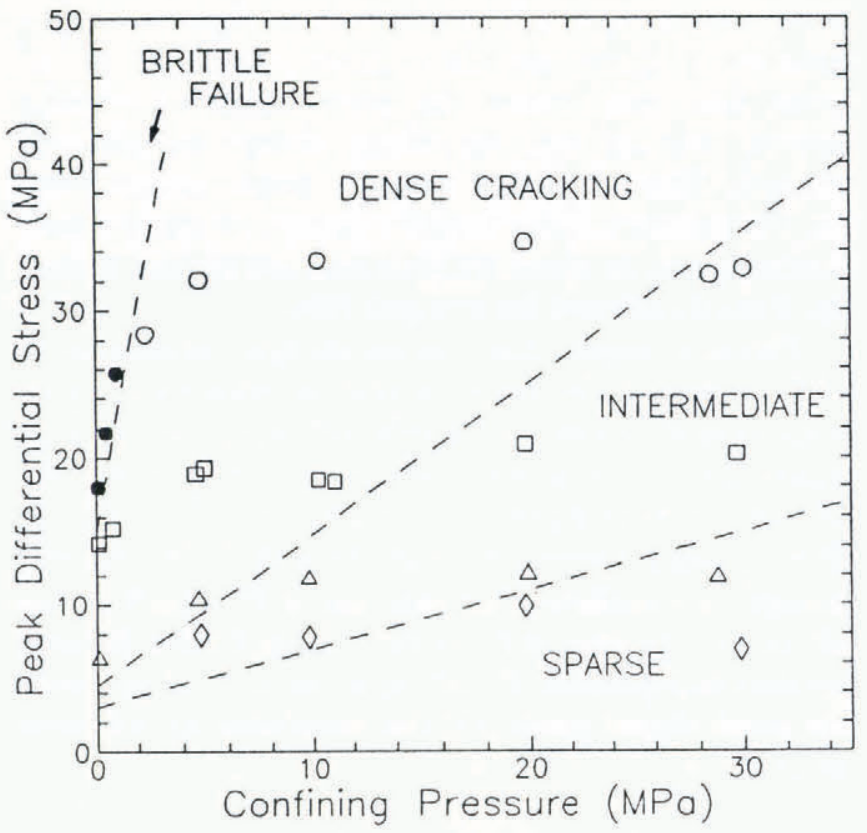

Fig. 6. Ice-strength and failure mode versus confining pressure at $-20^{\circ} \mathrm{C}$. Solid symbols denote brittle-shear fracture; others are ductile failures. $O=10^{-2} \mathrm{~s}^{-1}$; $\Delta=10^{-4} s^{-1} ; \square=10^{-3} s^{-1} ; \diamond=10^{-5} s^{-1}$.

low strain rates or for low crack densities. The strength or peak differential stress $\left(\sigma_{1}-\sigma_{3}\right)$ supported by each specimen at $-20^{\circ} \mathrm{C}$ is plotted versus confining pressure for each strain rate in Figure 6 and observed post-failure crack densities for the ductile specimens are also shown. It is apparent that the conditions under which brittle failure occurs at this temperature are quite limited, although a clear dependence of brittle-fracture strength on confining pressure is indicated for the $10^{-2} \mathrm{~s}^{-1}$ tests before a transition to ductile behaviour occurs above $P=1 \mathrm{MPa}$. The strength of the specimens that failed in a ductile manner depends on the strain rate but is independent of confining pressure, at least above $P=5 \mathrm{MPa}$, and it appears that the presence of cracks does not necessarily

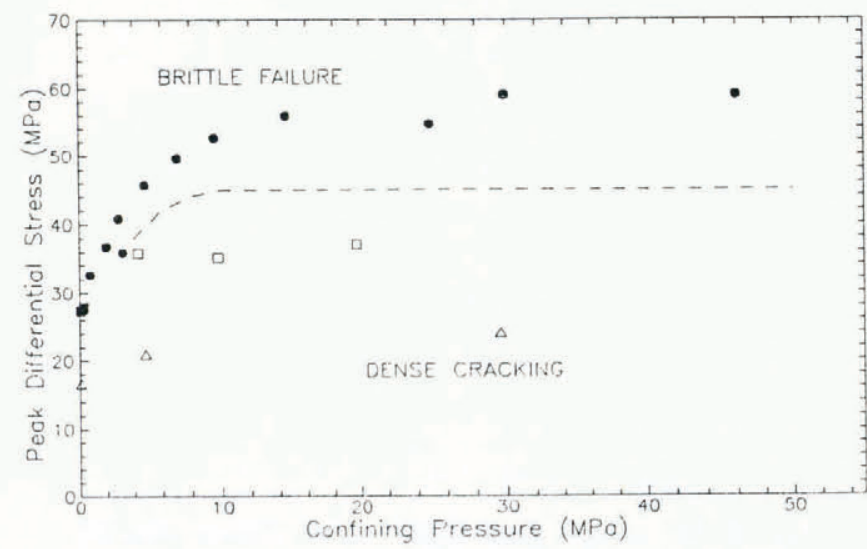

Fig. 7. Ice-strength and failure mode versus confining pressure at $-40^{\circ} \mathrm{C}$. Solid symbols denote brittle-shear fracture; others are ductile failures. $=10^{-2} \mathrm{~s}^{-1}$; $\triangle=10^{-4} s^{-1} ; \square=10^{-3} s^{-1}$. 
lower the strength of the ice even at high volumetric densities. In particular, the confined tests at the $10^{-4} \mathrm{~s}^{-1}$ strain rate span almost the whole range of cracking activity without any significant change in specimen strength. The maximum imposed mean normal stress $\left(\sigma_{\mathrm{m}}\right)$ at failure is about $40 \mathrm{MPa}$ and lowers the pressuremelting point by about $4^{\circ} \mathrm{C}$ but does not appear to have significantly affected the strength here.

Figure 7 shows that ductile-strength behaviour at $-40^{\circ} \mathrm{C}$ displays the same pressure-independence under non-uniaxial conditions. Brittle behaviour at the high strain rate for this temperature is not inhibited by increased confining pressure, at least up to $P=50 \mathrm{MPa}$. There is again a strong dependence of the brittle-fracture strength on confining pressure up to $P=10 \mathrm{MPa}$ but above this pressure the fracture strength also becomes pressure-independent. Cracking in the ductile specimens remained dense under all test conditions at this temperature.

\section{DISGUSSION}

\section{Ductile flow}

The ductile strength of ice can be considered as a ratesensitive yield stress and the differential failure stress for ductile deformation attained during constant strain-rate tests has been shown to be the same as the fixed stress required to induce a similar minimum strain rate ("secondary creep") in constant load-creep tests (Mellor and Cole, 1982, 1983). Pressure-independent ductilestrength data are therefore expected to follow the widely used power-law creep equation for ice:

$$
\dot{\epsilon}=A\left(\sigma_{1}-\sigma_{3}\right)^{n} \exp -\frac{Q}{R T}
$$

where $n$ and $A$ are material constants, $Q$ is the activation energy, $R$ is the molar gas constant and $T$ is the absolute

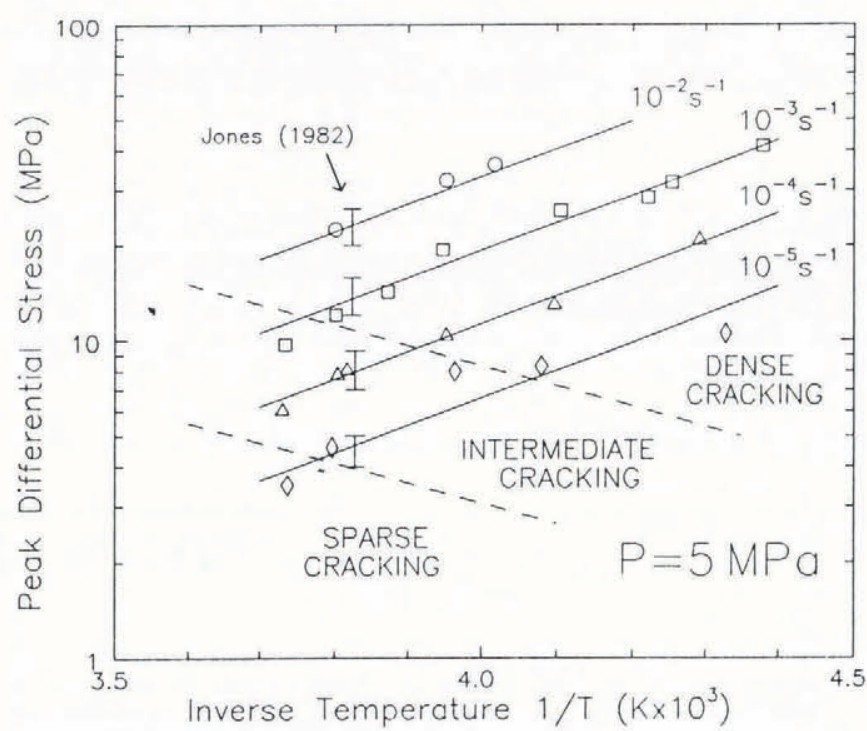

Fig. 8. Ice strength (log scale) versus inverse absolute temperature for specimens that failed in a ductile manner under a fixed confining pressure of $5 \mathrm{MPa}$. Bars indicate results of fones (1982) at $-11^{\circ} \mathrm{C}$ with $\mathrm{P}=5-30 \mathrm{MPa}$ and similar nominal strain rates. temperature. Figure 8 shows a plot of $\log \left(\sigma_{1}-\sigma_{3}\right)$ versus $1 / T$ covering temperatures $-5^{\circ}$ to $-45^{\circ} \mathrm{C}$ for ductile specimens with a fixed nominal $5 \mathrm{MPa}$ confining pressure. This figure indicates that the results correspond favourably with those of Jones (1982) at $-11^{\circ} \mathrm{C}$, the only other systematic triaxial study of pure granular ice under similar conditions. Jones did not observe a pressureindependence of strength as confinement was increased at this temperature because softening tended to occur at high values of the mean stress $\sigma_{\mathrm{m}}$. For this reason, a range of strengths for each comparable strain rate in Jones's study are indicated in Figure 8 , corresponding to confining pressures of 5-30 MPa.

Multiple linear-regression analysis of the current data (Fig. 8) by least-squares estimation provides the following values, with standard errors, for the material parameters in Equation (3).

$$
\begin{aligned}
Q & =69 \pm \mathrm{kJ} \mathrm{mol}^{-1} \\
n & =4.2 \pm 0.2 \\
\log A & =14 \pm 3 \mathrm{MPa}^{-n} \mathrm{~s}^{-1}
\end{aligned}
$$

(correlation coefficient $R^{2}=0.98$ ). Our value for the activation energy is in agreement with those derived by Barnes and others (1971) from uniaxial creep tests $\left(Q=75 \mathrm{~kJ} \mathrm{~mol}^{-1}\right)$, Budd and Jacka (1989) from an extensive range of borehole shear and laboratory compression tests $\left(Q=72 \mathrm{~kJ} \mathrm{~mol}^{-1}\right)$ and Sinha (1978) from an examination of the delayed elastic strain of columnar ice $\left(Q=67 \mathrm{~kJ} \mathrm{~mol}^{-1}\right)$. All these workers used comparatively low stresses $(<3 \mathrm{MPa})$ for which no cracking is expected and found $n \approx 3$ which is the widely accepted value reported in the literature under these conditions. This value has been taken by many to imply that creep is controlled by the drag experienced by dislocations in the basal plane, although the attainment of secondary creep has also been considered to be largely controlled by processes occurring on non-basal planes (e.g. Duval and others, 1983). At higher stresses, Barnes and others (1971) found that a simple power law was no longer valid as $n$ increased exponentially with stress. To estimate the change in the material parameters at higher stresses, they cited indentation hardness tests which produced a similar value for $Q$ of $73 \mathrm{~kJ} \mathrm{~mol}^{-1}$ at temperatures between $-12^{\circ}$ and $-25^{\circ} \mathrm{C}$ but a higher value for $n$ of around 4.4 for indentation pressures up to $50 \mathrm{MPa}$, in close agreement with the value found here.

It is generally considered that the increase in the stress exponent above $n=3$ is closely associated with the onset of microcracking. For example, Cole (1987) observed a change during uniaxial strength tests at $-5^{\circ} \mathrm{C}$, from $n=2.8$ in the strain-rate range $10^{-6} \mathrm{~s}^{-1}-10^{-7} \mathrm{~s}^{-1}$ with no apparent cracking (deformation being dominated by dynamic recrystallization) to $n=4.5$ at higher strain rates where microcracking and extensive grain-boundary deformation were observed. Jones (1982) found $n=5.0$ from uniaxial strength tests but $n=4.0$ under confinement, implying that the change was due to the inhibition of cracking. This may not be the case, however, since his confined strength data show no change in the linear relationship between $\log \left(\sigma_{1}-\sigma_{3}\right)$ and $\log (\dot{\boldsymbol{\epsilon}})$ (slope $=n$ ) from $10^{-7} \mathrm{~s}^{-1}$ (no cracking) to almost $10^{-2} \mathrm{~s}^{-1}$ where, presumably, cracking must have been extremely dense. 
Similarly, the strengths represented in Figure 8, used to calculate the flow parameters at $P=5 \mathrm{MPa}$, cover the whole range of observed cracking activity from purely ductile deformation (no cracks in specimen 93 at $-5^{\circ} \mathrm{C}$, $10^{-5} \mathrm{~s}^{-1}$ ) to flow accompanied by dense microcracking with no apparent discontinuity.

During the hardness tests reported by Barnes and others (1971), cracking was inhibited by an effective hydrostatic pressure and so the high value for $n$ must have been the result of some other mechanism enhanced by the high stresses - they suggested this reflects the importance of non-basal glide as a deformation process. Duval and others (1983) also questioned the extent of the influence of cracking on the creep behaviour of polycrystalline ice, finding no apparent effect of microcracking on the strain to the minimum creep rate or transition to tertiary flow.

Durham and others (1983) have found $n=4$ and $Q=91 \mathrm{~kJ} \mathrm{~mol}^{-1}$ for post-failure "steady-state" flow in constant deformation-rate triaxial tests over the temperature range $-15^{\circ}$ to $-30^{\circ} \mathrm{C}$ with $P=50 \mathrm{MPa}$. This confining pressure is sufficient to inhibit microcracking entirely but apparently leads to grain-boundary softening which increases the activation energy at temperatures higher than $-30^{\circ} \mathrm{C}$ (see Kirby and others 1987). Mellor and Testa (1969) and Barnes and others (1971) observed a change in activation energy above $-10^{\circ} \mathrm{C}$ which they associated with liquid at grain boundaries, a similar change not being observed in single crystals (Jones and Brunet, 1978). Below $-10^{\circ} \mathrm{C}$, Barnes and others (1971) considered only intergranular creep processes to be important. The $5 \mathrm{MPa}$ tests in Figure 8 cover the temperature range $-5^{\circ}$ to $-45^{\circ} \mathrm{C}$ but are too limited to identify any high-temperature regime.

\section{Brittle fracture}

Fracture of brittle polycrystalline materials in triaxial compression is widely regarded to be a multi-stage process involving crack nucleation, crack growth and crack interaction. In brittle rocks, crack nucleation is generally ignored as such materials are considered to contain numerous, randomly oriented, crack-type flaws from which growth can occur under favourable conditions. Laboratory-manufactured ice, on the other hand, although containing minute pores or bubbles, is generally considered to be flaw-free because such spheroidal inclusions appear not to act as nucleation sites for crack growth where they are small compared to the grain-size (Schulson and others, 1989; Shyam Sunder and Nanthikesan, 1990). Crack nucleation is therefore important and in polycrystalline ice has been considered to be the result of grain-boundary sliding (Sinha, 1984), dislocation pile-up at grain boundaries (Schulson and others, 1984; Cole, 1988) or the elastic anisotropy of the constituent crystals (Cole, 1988; Shyam Sunder and Wu, 1990). These studies, together with the other direct-crack observations (e.g. Gold, 1972; Kalifa and others, 1992) and acoustic emissions monitoring (St Lawrence and Cole, 1982; Rist and Murrell, 1990), all indicate that crack nucleation occurs well below the ultimate failure stress and that cracks initially remain stable. For this reason, it is assumed in the following discussion that crack nucleation and crack propagation are entirely separate processes, and that we may examine brittle-ice failure in terms of a body already containing distributed flaws. As mentioned previously, these flaws are not randomly oriented but are preferentially aligned with their long axes parallel to $\sigma_{1}$. However, Kalifa and others (1989) have observed this trend to weaken under triaxial stresses, and even under uniaxial stresses crack orientations up to $45^{\circ}$ and over are evident (Hallam and others, 1987). It is therefore likely that a wide variation in crack orientation exists but with greatly decreasing frequency of occurrence for high values of $\theta$.

Many investigations attempting to explain the compressive failure of brittle rocks have utilized Griffith energy-balance theories to explain the propagation of pre-existing crack-type flaws in a stressed elastic body (for a review see Paterson (1978)). Such theories assume that crack propagation will occur when the release of stored elastic energy associated with crack growth plus the work supplied by the external loading system is greater than the associated increase in surface energy of the new crack surface. A theoretical three-dimensional solution of crackgrowth initiation under triaxial stresses has been completed by Murrell and Digby (1970a) for a Griffithtype elastic body containing randomly orientated ellipsoidal cavities. The solution is achieved by first obtaining a maximum tensile-stress component for a cavity of fixed orientation with respect to the principal stress field, and then determining the cavity orientation for which the maximum local tensile stress is greatestthis maximum stress being set to equal the atomic cohesive strength of the material matrix. In the case of open penny-shaped cracks (having principal axes of length $a, b, c$ where $a=b \gg c)$, propagation initiates when

$$
\left(\sigma_{1}-\sigma_{3}\right)^{2}=(2-\nu)^{2} \sigma_{\mathrm{t}}\left[\sigma_{\mathrm{t}} \nu(4-\nu)+2\left(\sigma_{1}+\sigma_{3}\right)\right]
$$

where $\sigma_{\mathrm{t}}$ is the magnitude of the uniaxial tensile strength and $\nu$ is Poisson's ratio. The orientation of the most favourable crack for propagation is a function of the principal stresses and Poisson's ratio. Under uniaxial conditions $\theta=32^{\circ}$ is anticipated, rising to around $40^{\circ}$ for the largest brittle-failure stresses observed in the current study, although propagation is always predicted to occur in a direction normal to the least compressive stress, parallel to $\sigma_{1}$.

If the initial cracks or flaws are closed, or close up under compressive loading, then the normal stress acting across the crack faces, along with the frictional force that resists crack sliding, will become important. Murrell and Digby (1970b) modified their three-dimensional triaxial solution to accommodate closed cracks by assuming these forces are uniformly distributed over the crack surface. If cracks are always closed, or close at low stresses, the initiation criterion may be written:

$$
\sigma_{1}\left[\left(\mu^{2}+1\right)^{\frac{1}{2}}-\mu\right]-\sigma_{3}\left[\left(\mu^{2}+1\right)^{\frac{1}{2}}+\mu\right]=2(2-\nu) \sigma_{\mathrm{t}}
$$

where $\mu$ is the coefficient of friction between the crack faces. Under these conditions, the most favourable crack orientation is given by

$$
\tan 2 \theta=\frac{1}{\mu}
$$


although growth occurs in the direction of $\sigma_{1}$ as for open cracks.

The way in which normal and shear-surface stresses help to intensify the stress field near the tips of sharp cracks has been analysed more recently by Ashby and Hallam (1986) in order to explain the initiation and growth of out-of-plane crack extensions or wing cracks. Propagation is considered to commence when the mode I (tensile) stress-intensity factor at the crack tip reaches a critical value $K_{\text {IC }}$, the fracture toughness. For an initial crack of length $2 a$, the initiation condition, developed in two dimensions, is again derived by considering the maximum tensile stress for the most critical flaw and can be written

$$
\sigma_{1}\left[\left(\mu^{2}+1\right)^{\frac{1}{2}}-\mu\right]-\sigma_{3}\left[\left(\mu^{2}+1\right)^{\frac{1}{2}}+\mu\right]=\frac{\sqrt{3}}{\sqrt{\pi a}} K_{\mathrm{IC}}
$$

showing the same dependence on the principal stresses as Equation (5). In fact, when expressed in terms of normal and shear stresses, both Equations (5) and (7) take the Coulombic form

$$
|\tau|-\mu \sigma_{\mathrm{n}}=\text { constant }
$$

where $\sigma_{\mathrm{n}}$ and $\tau$ are defined in Equations (1) and (2). The most favourable flaw orientation for the wing-crack model is again given by Equation (6) and, although crack growth is initially at $70^{\circ}$ to the major axis of the original crack, the wing extension soon aligns itself in the $\sigma_{1}$ direction. Equation (5) may be expressed biaxially by replacing the $2(2-\nu)$ term on the righthand side with the constant 4 . If we assume that uniaxial tensile strength is determined by the propagation of a single crack perpendicular to the tensile-stress field, we may write (e.g. Lawn and Wilshaw, 1975):

$$
\sigma_{\mathrm{t}}=\frac{K_{\mathrm{IC}}}{\sqrt{\pi a}}
$$

so that the constant term $\sqrt{3}$ on the righthand side of Equation (7) corresponds to 4 in the two-dimensional expression of Equation (5). Hence, two different approaches using contrasting crack geometries (i.e. sharp versus elliptical) produce a virtually identical result. (In fact, Parsons (1991) suggested that cracks in ice remain atomically sharp due to a creep-deformed zone of dislocations partially shielding the crack from any external stress field and maintaining a dislocation-free zone around the crack tip.) If we put $K_{\mathrm{IC}}=0.1 \mathrm{MPa} \mathrm{m}^{\frac{1}{2}}$, the widely used fracture toughness value for ice, and $a=1 \times 10^{-3} \mathrm{~m}$ into Equation (9), then $\sigma_{\mathrm{t}}=1.8 \mathrm{MPa}$, in agreement with experimental values for ice of this grainsize (Schulson and others, 1984; Murrell and others, 1991).

The crack-propagation initiation criteria, Equations (4), (5) and (7), are plotted together with the observed brittle-ice fracture strengths at $-40^{\circ} \mathrm{C}$ in Figure 9. It should be emphasized that these theories do not predict macroscopic failure, although they might be expected to produce a similar trend. The figure demonstrates that, theoretically, brittle fracture is always influenced by confining pressure, more strongly where frictional forces are involved. Indeed, the strong pressure-dependence of ice brittle strength below $10 \mathrm{MPa}$ implies the influence of

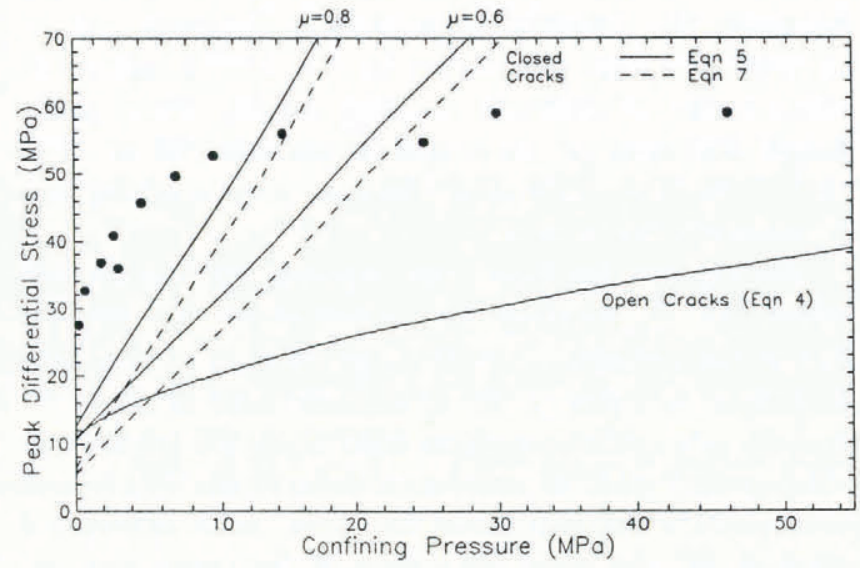

Fig. 9. Brittle-crack initiation criteria and observed fracture strengths for ice at $-40^{\circ} \mathrm{C}$.

friction. Ice fracture above $10 \mathrm{MPa}$ is pressure-independent, implying the underlying influence of plastic processes. A similar trend in brittle-fracture strength has also been identified by Schulson and others (1991) during deformation of ice under proportional triaxial loading $\left(R \sigma_{1}=\sigma_{2}=\sigma_{3}\right.$ where $\left.0<R<0.3\right)$. At $-40^{\circ} \mathrm{C}$, they observed mixed-mode shear and splitting fracture, displaying a strong pressure-dependence that became weaker above $R \approx 0.1(P \approx 3 \mathrm{MPa}$ at failure). Their complicated failure mode may have been influenced by significant end effects created by platens in contact with all six faces of cube-shaped specimens, direct comparison being difficult because of the different loading sequence, but the overall trend in strength behaviour is similar to that observed here.

The coefficient of friction for ice needs closer examination. This property has been investigated by a number of studies (Bowden and Hughes 1939; Evans and others, 1976; Oksanen and Keinonen, 1982; Akkok and others, 1987; Jones and others, 1991) generally at high temperatures and sliding rates where frictional heating leads to the formation of a water film to varying degrees and estimates of $\mu$ display a confusing diversity. On the other hand, Beeman and others (1988) have used triaxial apparatus to conduct friction tests on ice specimens with inclined sawcuts at low temperatures $\left(-196^{\circ}\right.$ to $\left.-158^{\circ} \mathrm{C}\right)$ and low sliding rates $\left(<3 \times 10^{-5} \mathrm{~m} \mathrm{~s}^{-1}\right)$ where a water film would not be a complicating factor. They observed a seemingly erratic stick-slip phenomenon from which they deduced different values of $\mu$ above and below a critical confining pressure of about $10 \mathrm{MPa}$, data being somewhat scattered. However, if we replot their stick-slip maxima, ignoring tests conducted at pressures high enough to induce a phase change, using axes of $\log \tau$ versus $\log \sigma_{\mathrm{n}}$, we get a well-defined frictional law, $\tau=1.5{\sigma_{\mathrm{n}}}^{0.65}$ (stresses in $\mathrm{MPa}$ ) as illustrated in Figure 10. Such behaviour is not unusual where a normal load causes increased contact at asperities between two sliding surfaces. Similar friction tests proved difficult to conduct using the UCL triaxial cell because the loading-strain arrangement often led to jacket rupture. However, a single sliding test on a polished $45^{\circ}$ sawcut was conducted successfully at $-40^{\circ} \mathrm{C}$ using a low confining pressure of $P=0.4 \mathrm{MPa}$ at a sliding rate of $\approx 10^{-5} \mathrm{~m} \mathrm{~s}^{-1}$, producing $\tau=3.7 \mathrm{MPa}$ and $\sigma_{\mathrm{n}}=$ $4.1 \mathrm{MPa}$ at the initiation of sliding. We may also deduce 


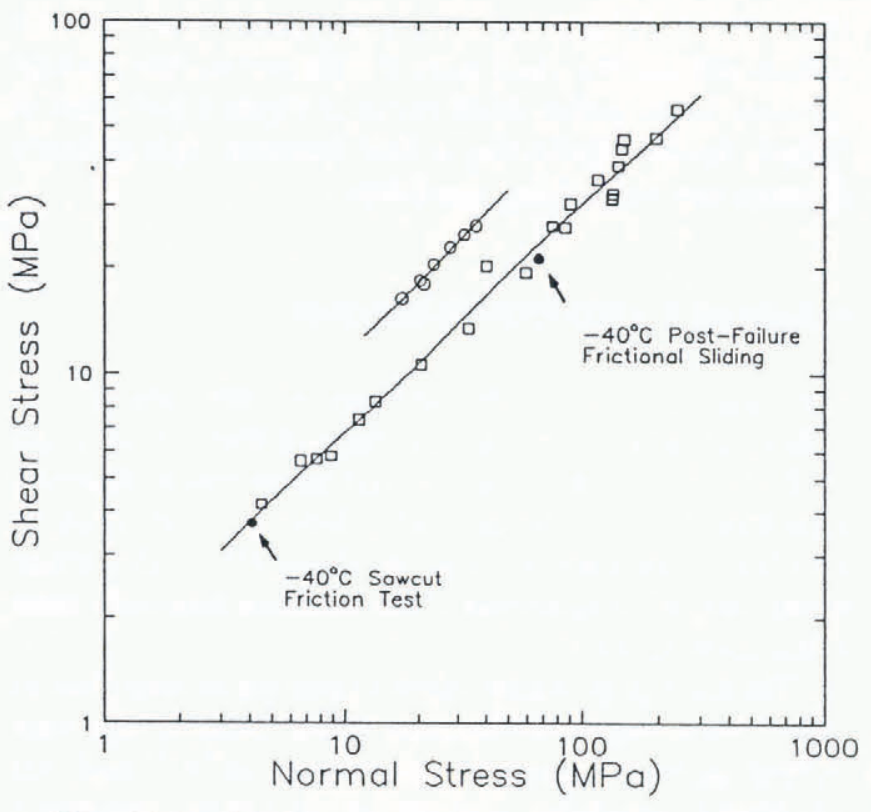

Fig. 10. Ice-friction behaviour at high stresses (Beeman and others, 1988) plotted together with pressure-dependent shear-fracture strengths, and other frictional measurements, observed during this study (see text for details). $\square \square \square$ friction tests $-158^{\circ}$ to $-196^{\circ} \mathrm{C}$ (Beeman and others, 1988); 0000 shear fracture $P<10 \mathrm{MPa}$ $-40^{\circ} \mathrm{C}$ (this study).

stick-slip sliding stresses from test 419 (Fig. 4) in which strength was regained after fracture and sliding proceeded along the failed fracture surface, giving $\tau=21.1 \mathrm{MPa}$ and $\sigma_{\mathrm{n}}=67.2 \mathrm{MPa}$ at $-40^{\circ} \mathrm{C}$ at a rate of $\approx 10^{-3} \mathrm{~m} \mathrm{~s}^{-1}$. Both these results are plotted on Figure 10 and comply closely with the proposed frictional law, implying that the behaviour is independent of temperature and sliding rate over a broad range.

The coefficient of friction for ice, as applied to the stick-slip behaviour described here, therefore depends on the imposed stresses and, if $\mu$ is an important factor in ice fracture, our pressure-dependent fracture strengths might be expected to show a similar trend as predicted by Equation (8). Indeed, plotting shear and normal stresses on the $45^{\circ}$ fracture surfaces at $-40^{\circ} \mathrm{C}$ for $P<10 \mathrm{MPa}$ in Figure 10 does produce an almost identical trend, $\tau \propto{\sigma_{\mathrm{n}}}^{0.67}$, although the data are somewhat limited. It should be noted, however, that the fracture angle does not appear to change with the stress state and hence is not dependent on $\mu$ in the manner predicted by Equation (6).

The brittle-propagation theories discussed above predict fracture initiation on the scale of internal cracks and crack growth in the direction of the maximum principal compressive stress. Since observations indicate that, on the macroscopic level, ice triaxial fracture does not occur by uncontrolled crack growth in this direction but by some shearing process, extensions to these theories are necessary to explain the failure process fully. Hallam (1986) has attempted to model crack interaction by specifying a critical value of the normalized crack extension $L=l / a$, where $l$ is the wing-crack length, for which ultimate failure will occur. Ashby and Hallam
(1986) and Sammis and Ashby (1986) used a damagemechanics approach in which crack extensions, growing from an array of inclined cracks or holes, divide the material body into a network of beams that allow the cracks to interact in such a way that they become unstable. However, even with cracks surrounding every grain, total crack dimensions of over half the ice-specimen length would be necessary to induce beam failure in our polycrystalline specimens under the triaxial stresses examined - at odds with the limited pre-failure axial cracking observed to accompany our brittle-shear fractured ice (Fig. 3b). Similarly, other triaxial damagemechanics models such as that of Costin (1983, 1985) which consider axial cracks only, extension being driven by the local tensile deviatoric stress normal to the crack surface, consider instability to occur at some critical state of damage when crack interaction becomes the dominant crack-driving force. Shear fracture is not accounted for and, indeed, is considered part of post-failure behaviour. This is not an unusual assumption in rock mechanics, since it has been demonstrated (e.g. Hallbauer and others, 1973) that initially randomly distributed cracks in brittle rocks coalesce near the peak stress but sliding along a shear plane (effectively macroscopic fracture) often does not occur until after the maximum load, during the ensuing strain softening. The brittle-deformation behaviour of ice represented in Figure 2 does not conform to this interpretation. The stress-strain curve displays little evidence of accumulating shear damage before failure, and no hint of roll-over in the stress-strain curve; fracture occurs abruptly despite the ability of the test-system apparatus to unload ice in a controlled manner at rates over 3 tonnes per second $\left(>20 \mathrm{MPa} \mathrm{s}^{-1}\right.$ ) (Rist and others, 1991). Neither is the suddenness of failure merely a consequence of the high strain rate used here, since Durham and others (1983), working at much lower temperatures, have noted similar behaviour at strain rates as low as $4 \times 10^{-6} \mathrm{~s}^{-1}$, albeit using non-servo-controlled apparatus of unspecified stiffness. In fact, the shape of the brittle compressive ice-deformation curve can be compared to that of ice brittle fracture in tension (Schulson and others, 1984; Murrell and others, 1991) where failure is thought to occur by the unstable propagation of a single flaw.

Although it is widely considered that a crack in a brittle isotropic medium does not propagate in its own plane, certain unique aspects of ice-shear fracture behaviour indicate that we may nevertheless be dealing with a true shear process. Durham and others (1983) argued that the $45^{\circ}$ fracture angle in the direction of maximum shear stress, which is rarely observed in brittle rocks except when influenced by jointing or other structural features, is consistent with the mechanism being fundamentally a shearing process. Recent observations by Rist and others (1994) indicate that the fracture surface propagates at least as fast as $100 \mathrm{~m} \mathrm{~s}^{-1}$ and that no large-scale volumetric changes accompany the failure process - at odds with the concept of interacting tensile microcracks creating a damaged process zone. Kemeny and Cook (1987) have examined a model in which they consider an elastic material containing a collinear row of shear cracks growing in their own plane. If was found that such an arrangement is always unstable once crack 
growth commences, unlike out-of-plane crack extension which is initially stable. They suggested that such a mechanism for shear faulting comes into play at high confining pressure in rocks when axial crack growth is limited, explaining the transition from axial splitting to shear fracture. Experimental evidence we have presented indicates that axial crack growth in ice appears to remain remarkably stable under even the smallest triaxial stresses, perhaps allowing unstable propagation to result from favourably aligned shear cracks even though observed microcracking is predominantly axial.

As has already been pointed out, brittle-fracture theories are inherently pressure-dependent and the pressure-independent fracture above $P=10 \mathrm{MPa}$ requires separate discussion. Similar behaviour has been observed by Durham and others (1983) at much lower temperatures, $-115^{\circ}$ to $196^{\circ} \mathrm{C}$, at strain rates below $10^{-4}$ $\mathrm{s}^{-1}$. They found fracture strength to be independent of pressure above $P=50 \mathrm{MPa}$, although they did not investigate lower pressures fully, and also observed that fracture was not inhibited by pressures up to $350 \mathrm{MPa}$, strength remaining constant until a bulk phase change (to ice II) occurred in some cases. In fact, Kirby (1987) has proposed that pressure-independent ice-shear fracture is due to shear instability caused by localized phase change to ice II provided that the mean stress, $\sigma_{\mathrm{m}}$, is in the ice II stability field. This appears not to be the case here; even under the most severe loading conditions macroscopic mean stresses remain well away from any solid or liquid phase change at $-40^{\circ} \mathrm{C}$, although high localized microstructural stresses cannot be ruled out. Smith and Schulson (1993) have observed high-pressure weakening during fracture of columnar ice under biaxial compression at $-10^{\circ}$ and $-40^{\circ} \mathrm{C}$. They proposed that new tensile fractures caused by Hertzian contact between asperities on previously formed crack surfaces can propagate to failure at lower stresses than expected. However, this is only possible because their loading arrangement has a component in which the confining stress disappears, whereas crack propagation in triaxial compression is always expected to be pressure-dependent as described above.

The pressure-independence of ice strength may indicate the influence of crystal plasticity on crack propagation. Plastic deformation of a single ice crystal takes place easily by slip on the crystallographic basal plane at low stresses (Jones and Glen, 1969; Jones and Brunet, 1978) which are less than those observed for polycrystalline crack nucleation (Kalifa and others, 1989, 1992). On the other hand, significant deformation on non-basal systems may only take place at stresses at least an order of magnitude higher and may dominate polycrystal yield at high stresses (see Ashby and Duval (1985), for a discussion). If this is the case, then localized yielding of favourably oriented crystals at high stress may trigger the instability that leads to the observed fracture behaviour, independent of the imposed confinement, just before the transition to general polycrystal yield can occur. The ductile strength for polycrystalline ice predicted by Equation (3), for a strain rate of $10^{-2} \mathrm{~s}^{-1}$ at $-40^{\circ} \mathrm{C}$ using our derived creep parameters, is $60 \mathrm{MPa}$, and this coincides precisely with the limiting fracture strength observed in this study (see Fig. 9). Indeed, the fact that high-pressure fracture occurs close to the polycrystal ductile yield stress is reflected by the marked turnover in the stress-strain curve of Figure 4 just prior to failure, further indicating a link between high-pressure fracture and underlying plasticity.

\section{SUMMARY AND CONCLUSIONS}

We have systematically investigated the mechanical behaviour of pure isotropic polycrystalline ice of small $(\approx 2 \mathrm{~mm})$ grain-size under triaxial compression. Ductiletype flow, often accompanied by dense internal cracking and brittle fracture, inclined at about $45^{\circ}$ to the major stress axis, were observed. These failure processes were remarkably distinct.

The conditions under which brittle failure occurred at $-20^{\circ} \mathrm{C}$ were somewhat limited. Shear fracture was only evident at the highest strain rate used, $10^{-2} \mathrm{~s}^{-1}$, and was inhibited by confining pressures above $1 \mathrm{MPa}$, allowing a transition to ductile flow with distributed microcracking to occur.

At $-40^{\circ} \mathrm{C}$, triaxial shear fracture was still only observed at high strain rate but in this case was not suppressed by confining pressures up to at least $50 \mathrm{MPa}$. Strongly pressure-dependent behaviour for $P<10 \mathrm{MPa}$ implied the influence of friction in the fracture process. At higher pressures, brittle-fracture strength was pressureindependent, an effect not observed in other polycrystalline materials, indicating the underlying influence of plastic processes. The observed stress-strain behaviour, the nature of the shear fracturing and the pressureindependence all indicate a fracture process that is not dependent on a critical crack density. Rather, it is suggested that unstable in-plane crack propagation, frictional in nature at low stresses but induced at high pressures by local yielding, may be the cause of the extraordinary fracture behaviour.

Ductile yield strength was also independent of confining pressure, despite greatly contrasting apparent crack densities. The derived activation energy and powerlaw exponent for flow at temperatures between $-20^{\circ}$ and $-45^{\circ} \mathrm{C}$ were in agreement with those found elsewhere for pure creep at high stresses. The overall implication is that microcracking in ice is exceptionally stable and noninteracting over a wide range of conditions.

\section{ACKNOWLEDGEMENTS}

The experimental work in this study was conducted at University College London and funded by the U.K. Natural Environment Research Council (NERC).

\section{REFERENCES}

Akkok, M., C. M. McC. Ettles and S.J. Calebrese. 1987. Parameters affecting the kinetic friction of ice. Trans. Am. Soc. Mech. Eng. J. Tribology, 109, 552-561.

Ashby, M.F. and P. Duval. 1985. The creep of polycrystalline ice. Cold Reg. Sci. Technol., 11(3), 285-300.

Ashby, M.F. and S.D. Hallam. 1986. The failure of brittle solids containing small cracks under compressive stress states. Acta Metallurgica et Materialia, 34(3), 497-510 
Barnes, P., D. Tabor and J. C.F. Walker. 1971. The friction and creep of polycrystalline ice. Proc. R. Soc. London, Ser. A, 324(1557), 127-155.

Beeman, M., W.B. Durham and S.H. Kirby. 1988. Friction of ice. 7 . Geophys. Res., 93(B7), 7625-7633.

Bowden, F. P. and T. P. Hughes. 1939. The mechanism of sliding on ice and snow. Proc. R. Soc. London, Ser. A, 172(949), 280-298.

Brady, B. T. 1971. The effect of confining pressure on the elastic stress distribution in a radially end-constrained circular cylinder. Int. $\mathcal{F}$. Rock Mech. Min. Sci. Geomech. Abstr., 8, 153-164.

Budd, W. F. and T. H. Jacka. 1989. A review of ice rheology for ice sheet modelling. Cold. Reg. Sci. Technol., 16(2), 107-144.

Cole, D. M. 1987. Strain-rate and grain-size effects in ice. f. Glaciol., 33(115), 274-280.

Cole, D. M. 1988. Crack nucleation in polycrystalline ice. Cold Reg. Sci. Technol., 15(1), 79-87.

Costin, L.S. 1983. A microcrack model for the deformation and failure of brittle rock. F. Geophys. Res., 88(B11), 9485-9492.

Costin, L. S. 1985. Damage mechanics in the post-failure regime. Mech. Mater., 4, 149-160.

Cox, G.F.N. and J.A. Richter-Menge. 1986. Confined compressive strength of multi-year pressure ridge sea ice samples. In Lunardini, V.J., Y. S. Wang, O. A. Ayorinde and D. V. Sodhi, eds. Proceedings of the Fifth International Mechanics and Arctic Engineering (OMAE) Symposium ..., Tokyo, Japan, April 13-18, 1986... Vol. 4. New York, American Society of Mechanical Engineers, 365-373.

Doake, C. S. M. and D.G. Vaughan. 1991. Rapid disintegration of the Wordie Ice Shelf in response to atmospheric warming. Nature, 350(6316), 328-330.

Durham, W.B., H.C. Heard and S.H. Kirby. 1983. Experimental deformation of polycrystalline $\mathrm{H}_{2} \mathrm{O}$ ice at high pressure and low temperature: preliminary results. F. Geophys. Res., 88, Supplement, Part 1, B377-B392.

Duval, P., M.F. Ashby and I. Andermann. 1983. Rate-controlling processes in the creep of polycrystalline ice. F. Phys. Chem., 87(21), 4066-4074.

Evans, D. C.B., J.F. Nye and K.J. Cheeseman. 1976. The kinetic friction of ice. Proc. R. Soc. London, Ser. A., 347(1651), 493-512.

Gold, L. W. 1972. The process of failure of columnar-grained ice. Philos. Mag., 26(2), 311-328.

Hallam, S. D. 1986. The role of fracture in limiting ice forces. In International Association for Hydraulic Research. 8th International Symposium on Ice, Iowa City, August 18-22, 1986. Vol. 2. Iowa City, IA, University of Iowa. Institute of Hydraulic Research, 287-319.

Hallam, S. D., P. Duval and M.F. Ashby. 1987. A study of cracks in polycrystalline ice under uniaxial compression. J. Phys. (Paris), 48, Collog. C1, 303-311. (Supplément au 3.)

Hallbauer, D. K., H. Wagner and N.G.W. Cook. 1973. Some observations concerning the microscopic and mechanical behaviour of quartzite specimens in stiff, triaxial compression tests. Int. F. Rock Mech. Min. Sci. Geomech. Abstr., 10, 712-726.

Häusler, F. U. 1981. Multiaxial compressive strength tests on saline ice with brush-type loading platens. In IAHR International Symposium on Ice, Québec, Canada, fuly 27-31, 1981. Proceedings. Vol. II. Québec, Université Laval, 526-536.

Hughes, T. 1983. On the disintegration of ice shelves: the role of fracture. F. Glaciol., 29(101), 98-117.

Jacka, T.H. and R.C. Lile. 1984. Sample preparation techniques and compression apparatus for ice flow studies. Cold Reg. Sci. Technol., 8(3), 235-240.

Jaeger, J. C. and N.G.W. Cook. 1979. Fundamentals of rock mechanics. Third edition. London, Chapman and Hall.

Jones, D. E., F.E. Kennedy and E.M. Schulson. 1991. The kinetic friction of saline ice against itself at low sliding velocities. Ann. Glaciol., 15, 242-246.

Jones, S.J. 1982. The confined compressive strength of polycrystalline ice. F. Glaciol., 28(98), 171-177.

Jones, S.J. and J.-G. Brunet. 1978. Deformation of ice single crystals close to the melting point. F. Glaciol., 21(85), 445-455.

Jones, S.J. and J.W. Glen. 1969. The mechanical properties of single crystals of pure ice. F. Glaciol., 8(54), 463-473.

Kalifa, P., P. Duval and M. Ricard. 1989. Crack nucleation in polycrystalline ice under compressive stress states. In Sinha, N. K., D. S. Sodhi and J.S. Chung, eds. Proceedings of the Eighth International Conference on Offshore Mechanics and Arctic Engineering, The Hague, The Netherlands, March 19-23, 1989. Vol. 4. Arctic and polar technology. New York, American Society of Mechanical Engineers, 13-21.
Kalifa, P., G. Ouillon and P. Duval. 1992. Microcracking and the failure of polycrystalline ice under triaxial compression. F. Glaciol., 38(128), 65-76.

Kemeny, J. M. and N. G. W. Cook. 1987. Crack models for the failure of rocks in compression. In The 2nd International Conference on Constitutive Laws for Engineering Materials. Proceedings. Vol. 2, 879-887.

Kirby, S.H. 1987. Localized polymorphic phase transformations in high-pressure faults and applications to the physical mechanism of deep earthquakes. J. Geophys. Res., 92(B13), 13,789-13,800.

Kirby, S. H., W.B. Durham, M. L. Beeman, H. C. Heard and M. A. Daley. 1987. Inelastic properties of ice $\mathrm{I}_{\mathrm{h}}$ at low temperatures and high pressures. 7. Phys. (Paris), 48, Collog. C1, 227-232. (Supplément au 3.)

Lawn, B.R. and T.R. Wilshaw. 1975. Fracture of brittle solids. Cambridge, Cambridge University Press.

Mellor, M. and D. M. Cole. 1982. Deformation and failure of ice under constant stress or constant strain-rate. Cold Reg. Sci. Technol., 5(3), 201-219.

Mellor, M. and D.M. Cole. 1983. Stress/strain/time relations for ice under uniaxial compression. Cold Reg. Sci. Technol., 6(3), 207-230.

Mellor, M. and R. Testa. 1969. Effect of temperature on the creep of ice. 7. Glaciol., 8(52), 131-145.

Murrell, S. A. F. and P.J. Digby. 1970a. The theory of brittle fracture initiation under triaxial stress conditions. Part I. F. R. Astron. Soc., 19, 309-334.

Murrell, S. A.F. and P.J. Digby, 1970b. The theory of brittle fraction initiation under triaxial stress conditions. Part II. F. R. Astron. Soc., 19, 499-512.

Murrell, S. A. F., P.R. Sammonds and M. A. Rist. 1991. Strength and failure modes of pure ice and multi-year sea ice under triaxial loading. In Jones, S.J., R.F. McKenna, J. Tillotson and I.J. Jordaan, eds. Ice-Structure Interaction. IUTAM/IAHR Symposium, St. John's, Newfoundland, Canada 1989. Berlin, Springer-Verlag, 339-361.

Nadreau, J. P. and B. Michel. 1986. Yield and failure envelope for ice under multiaxial compressive stresses. Cold Reg. Sci. Technol., 13(1), 75-82.

Oksanen, P. and J. Keinonen, 1982. The mechanism of friction of ice. Wear, 78, 315-324.

Parsons, B. L. 1991. Discussion. The tensile strength of cracked ice by E. M. Shulson, S. G. Hoxie, W.A. Nixon. Cold Reg. Sci. Technol., 19(2), 221-222.

Paterson, M.S. 1978. Experimental rock deformation - the brittle field. Berlin, Springer-Verlag.

Rist, M.A. and S. A. F. Murrell. 1990. Examination of the semi-brittle uniaxial and triaxial deformation behaviour of polycrystalline ice using acoustic emission measurement techniques. In Murthy, T. K. S., J. G. Paren, W. M. Sackinger and P. Wadhams, eds. Ice technology for polar operations. Proceedings of the Second International Conference on Ice Technology,... Cambridge University, UK... 18-20 September 1990. Southampton, Computational Mechanics Publications, 91-102.

Rist, M.A., P.R. Sammonds and S.A.F. Murrell. 1991. Strain rate control during deformation of ice: an assessment of the performance of a new servo-controlled triaxial testing system. Cold Reg. Sci. Technol., 19(2), 189-200.

Rist, M. A., S. J. Jones and T. D. Slade. 1994. Microcracking and shear fracture in ice. Ann. Glaciol., 19.

St. Lawrence, W.F. and D. M. Cole. 1982. Acoustic emissions from polycrystalline ice. Cold Reg. Sci. Technol., 5(3), 183-199.

Sammis, C. G. and M. F. Ashby. 1986. The failure of brittle porous solids under compressive stress states. Acta. Metallurgica et Materialia, 34(3), 511-526.

Sammonds, P.R., S. A. F. Murrell and M. A. Rist. 1989. Fracture of multi-year sea ice under triaxial stresses: apparatus description and preliminary results. 7. Offshore Mech. Arct. Eng., 111, 258-263.

Sammonds, P. R., S. A. F. Murrell, M. A. Rist and D. Butler. 1991. The design of a high-pressure low-temperature triaxial deformation cell for ice. Cold Reg. Sci. Technol., 19(2), 177-188.

Sanderson, T.J. O. 1988. Ice mechanics; risks to offshore structures. London, Graham and Trotman.

Schulson, E. M., P.N. Lim and R.W. Lee. 1984. A brittle to ductile transition in ice under tension. Philos. Mag. A, 49(3), 353-363.

Schulson, E.M., S.G. Hoxie and W.A. Nixon. 1989. The tensile strength of cracked ice. Philos. Mag. A, 59(2), 303-311.

Schulson, E. M., D.E. Jones and G. A. Kuehn. 1991. The effect of 
confinement on the brittle compressive fracture of ice. Ann. Glaciol., 15, 216-221.

Sinha, N. K. 1978. Rheology of columnar-grained ice. Exp. Mech., 18(12), $464-470$.

Sinha, N.K. 1984. Intercrystalline cracking, grain boundary sliding, and delayed elasticity at high temperatures. J. Mater. Sci., 19(2), 359-376.

Smith, T.R. and E. M. Schulson. 1993. The brittle compressive failure of fresh-water columnar ice under biaxial loading. Acta Metallurgica et Materialia, 41(1), 153-163.

Stone, B. M., I.J. Jordaan, S.J. Jones and R. F. McKenna. 1989. Damage of isotropic polycrystalline ice under moderate confining pressures. In Axelsson, K. B. E. and L. A. Fransson, eds. POAC 89. The 10th International Conference on Port and Ocean Engineering under Arctic
Conditions, June 12-16, Luled, Sweden. Proceedings. Vol. 1. Luleå, Tekniska Högskolan i Luleå, 408-419.

Sunder, S.S. and S. Nanthikesan. 1990. Crack nucleation due to elastic anisotropy in porous ice. Cold. Reg. Sci. Technol., 18(3), 249-265.

Sunder, S.S. and M.S. Wu. 1990. Crack nucleation due to elastic anisotropy in polycrystalline ice. Cold Reg. Sci. Technol., 18(1), $29-47$. Vaughan, D.G. 1993. Relating the occurrence of crevasses to surface strain rates. F. Glaciol., 39(132), 255-266.

The accuracy of references in the text and in this list is the responsibility of the authors, to whom queries should be addressed.

MS received 18 February 1993 and in revised form 16 fuly 1993 